\title{
The Symbolic Use of Whetstones and Their Role in Displaying Authority over Metallurgical Processes and Trade
}

\begin{abstract}
Whetstones of the Viking Age can have a conspicuous design, but not much is understood about the specific use of more unusual specimens, or their place in rituals. This article proposes a new interpretation of whetstones, based on novel studies of a well-known whetstone from Lejre, and miniature pendants from Tissø. Our examination of the prominent whetstone from the Lejre hoard with an x-ray fluorescence (XRF) scan, did not reveal any metal traces, which suggests that it was unused. At Tissø, the find distribution of so-called stafflike pendants - made of iron, bronze, or silver - links them to a metal-working area, and since their morphology resembles full-scale whetstones we suggest that they may be symbolic, miniature whetstones. Finally, we argue that the overarching meaning of the ritual use of whetstones is more related to the authority over - and control of - metallurgical processes, as well as the trade of metal goods, and only by proxy to the smith himself.
\end{abstract}

\section{Introduction}

The perhaps most renowned Norse saga description of a whetstone is found in Haustlong where Pórr (Eng: Thor) battles the fearsome giant Hrungnir (Faulkes 1998: 22-21). The actual battle seems to consist of one single melee, and during the clash with the god, Hrungnir throws his weapon, a whetstone, which is shattered mid-air by Mjollnir, and lodges small, nearly deadly, splinters in Pórr's forehead. However, the battle ends when Hrungnir is killed by a blow from Pórr's hammer Mjǫllnir.

In this article, we will investigate symbolic aspects of Viking Age whetstones. Our starting point is a reevaluation of a large, broken, and unused whetstone, which was part of the famous Lejre hoard found in 1850, and the reasons behind it being broken and unused. By comparing it to other finds, including ones from Tissø, we hypothesise that originally it expressed authority over metallurgical processes and trade.

Whetstones are recurring objects in the Northern European Late Iron Age and Viking Period archaeology, and must have been common personal items. Accounts of whetstones are found in mythology, saga literature, and as royal cognomen but most prominently they 
occur as grave finds, and in votive deposits related to the highest societal strata. Some even carry conspicuous runic inscriptions, thus emphasising the special nature of these otherwise mundane objects.

Consequently, this article will investigate the intricate relationship between the commonality and rituality of whetstones, with particular foci on symbolic references to the king as a warlord, their use for honing weapons, and their production.

Our own analyses are twofold: Firstly, through an x-ray fluorescence (XRF) surface scan of the whetstone from the Lejre hoard, to examine whether this particular stone was ever used for honing (or other purposes), including a scientific assessment of the actual user context for this particular stone. Secondly, a detailed examination of a recently found bronze object from the aristocratic complex at Tiss $\varnothing$ - which resembles a whetstone - will be used as an entry point for exploring the symbolic connection between whetstones and miniature pendants. Jointly, the two approaches will be used as foundations for examining the Viking Age aristocracy's use of whetstone symbolism and how this relates to the control of metalworkers and their products. Initially, however, we will look at historical references to whetstones.

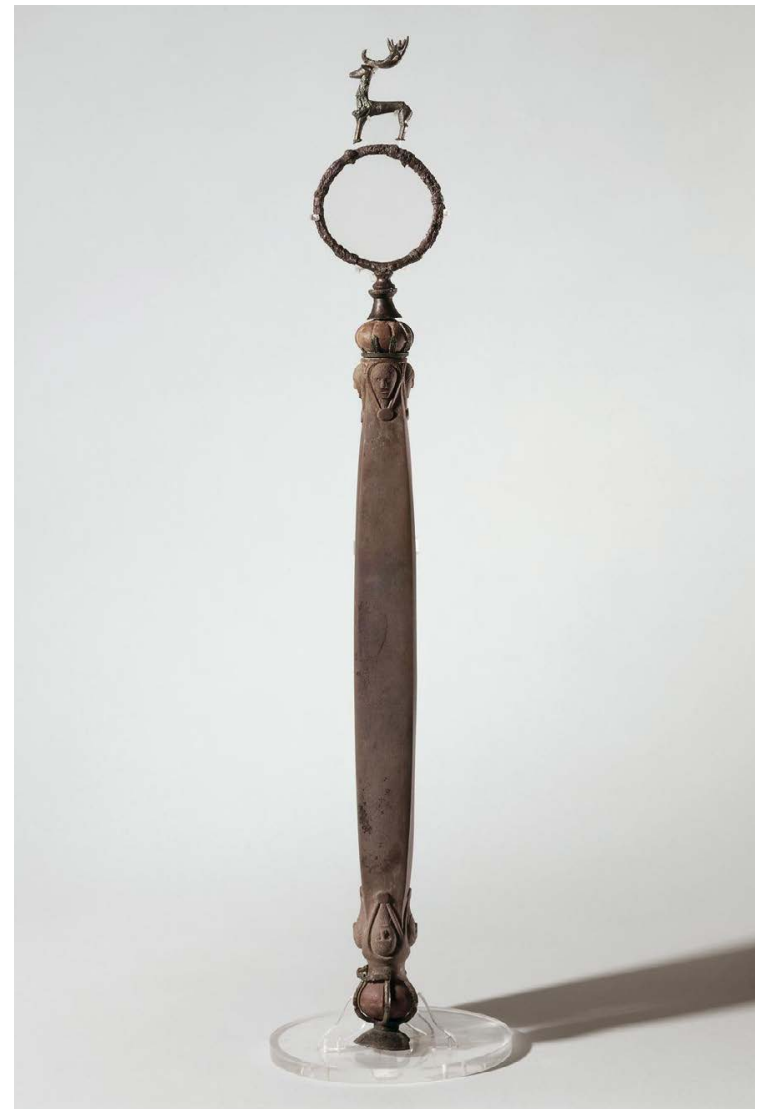

Figure 1. A central element of the Sutton Hoo sceptre contains a bar of fine-grained sandstone. It is adorned with four faces at either end, and a copper alloy stag figurine at the top. Photo: British Museum. CC BY-NC-SA 4.0 


\section{Background}

Whetstones and knives are common personal effects found in many archaeological contexts (Mitchell, Askvik \& Resi 1984; Resi 2011; Pedersen 2014: 129-30; Baug, Skre, Heldal et al. 2019). Some more intriguing specimens, with conspicuous characteristics, appear in contexts that suggest an aristocratic relationship. The most prominent archaeological whetstone find is a large (58.3 cm in length), and very ornate piece from a Sutton Hoo ship burial (Mound 1), which clearly indicates that it was something other than a large and special type of whetstone. This specimen, which has often been denoted as a sceptre (Bruce-Mitford 1978: 311; Simpson 1979; Enright 1983, 2006; Quast 2010: 285), comprises a four-sided stone bar of hard, fine-grained grey schist (Fig. 1). The ends, which are tapered and carved, would originally have been painted red. The bottom end is attached to a cup-shaped piece of copper alloy, and the top to an iron ring adorned with a copper alloy stag. Four human faces are carved at either end of the stone. Its surfaces are extremely smooth and show very few traces of wear, even though the size suggests that it was a stone intended for sharpening swords and/or other weapons.

There are several interpretations as to why this rather common stone has ended up in a top echelon burial. They range from Michael J. Enright's reference to the stone and staff as a royal insignia. He believes it originates in a Celtic royal context where such items functioned as sceptres with metallurgical connotations (1983, 2006: 10). Others see an elaborate symbolic connection to an ahnenstab, (Germ: an ancestral staff) with links to the multi-faced god Óðinn (Eng: Odin), as theorised by Karl Hauck (1954), or to the mythological and metaphorical relationship to the material itself: a hard stone type symbolising a hard but just ruler, as Stephen Mitchell has suggested (1985). More recently, Neil Price and Paul Mortimer (2014) have pointed to the intricate and time-consuming work that went into one of the eyes on one of the eight heads, adorning the whetstone. They suggest that this could be a rendition of the one-eyed god, Óðinn (ibid: 528-30), thus reinforcing the Odinic connotations to an ahnenstab, as described by Hauck, and at the same time dismissing the Celtic reference argued by Enright (see Mortimer 2013 for a similar conclusion). In combination, the iconography of the Sutton Hoo whetstone implies a royal (possibly Odinic) heritage - symbolising the essence of a regal insignia ${ }^{1}$ - whereas the materiality of the very hard stone, with harðsteinn (ON for hard stone) being a possible cognomen for kingship itself (cf. Mitchell 1985: 18), emphasising the function of these types of very large whetstones for sharpening weapons. The use of subtle visual, as well as tangible allusions to Óðinn, the warrior god, would emphasise the sacred character of the bearer (Nygaard 2016), while also acknowledging this person as responsible for sharpening weapons and equipping warriors. Thus, a common denominator for the interpretations of the Sutton Hoo whetstone seems to be the recognition of the bearer as a warlord of divine ancestry - quite likely linked to Óðinn.

In addition to the Haustlong example in the introduction, another reference in written sources can be found in Skáldskaparmál where Bragi tells the story of how Óðinn acquires the mead of poetry by honing the scythes of nine farmers, who then kill each other with the honed scythes during a fight over the wonderful whetstone. Óðinn then gets the opportunity to work for Baugi, the brother of Suttungr, who leads him to the mead (Faulkes 1998: 4-6).

There is another short reference to whetstones in the Sverris saga, specifically during the Battle at Fimreite, where King Sverre's main ship is attacked by the Heklungar followers of 
Magnus Erlingsson, and they throw arrows, spears and whetstones, which were, as it is written: ‘the greatest danger to man' (Storm \& Bugge 1914: 91).

Another reference linking a monarch to a whetstone is connected to the Danish King Harald III (AD 1041-80), who is more commonly known by his byname 'Hen', which can mean whetstone, but in this case with several possible caveats. It could either imply 'soft stone', in the sense of Harald being a soft king inclined to follow public opinion, or a direct reference to the function of the whetstone itself, to sharpen weapons. The latter reference would also - to some extent - align with the life of Harald 'Hen' as he was responsible for mustering the fleet - the leðing - for the later abandoned 1069 Danish attack on England (Lauring 1979: 76-8). As argued by Stephen Mitchell, the byname is probably meant as an inverted, or ironic description. Comparing the ruler to a whetstone truly symbolises royal authority, but in this case it also becomes a ridicule, since 'hen' denotes a softer fine-grained stone, not a hard stone, and is a feminine noun. In more direct terms it describes Harald as a weak and lenient ruler (Mitchell 1985: 16-7).

These references to whetstones are certainly very diverse, however, in addition to the possible magical traits of the stones, there are also recurring themes of war and struggle where the actual stones sometimes are dangerous elements. This leads to further questions: if the martial uses of whetstones were related to the gods themselves, as well as to Scandinavian royals, where might these relationships between hard stone types and royalty stem from, and how did this link develop prior to the historical and literary accounts?

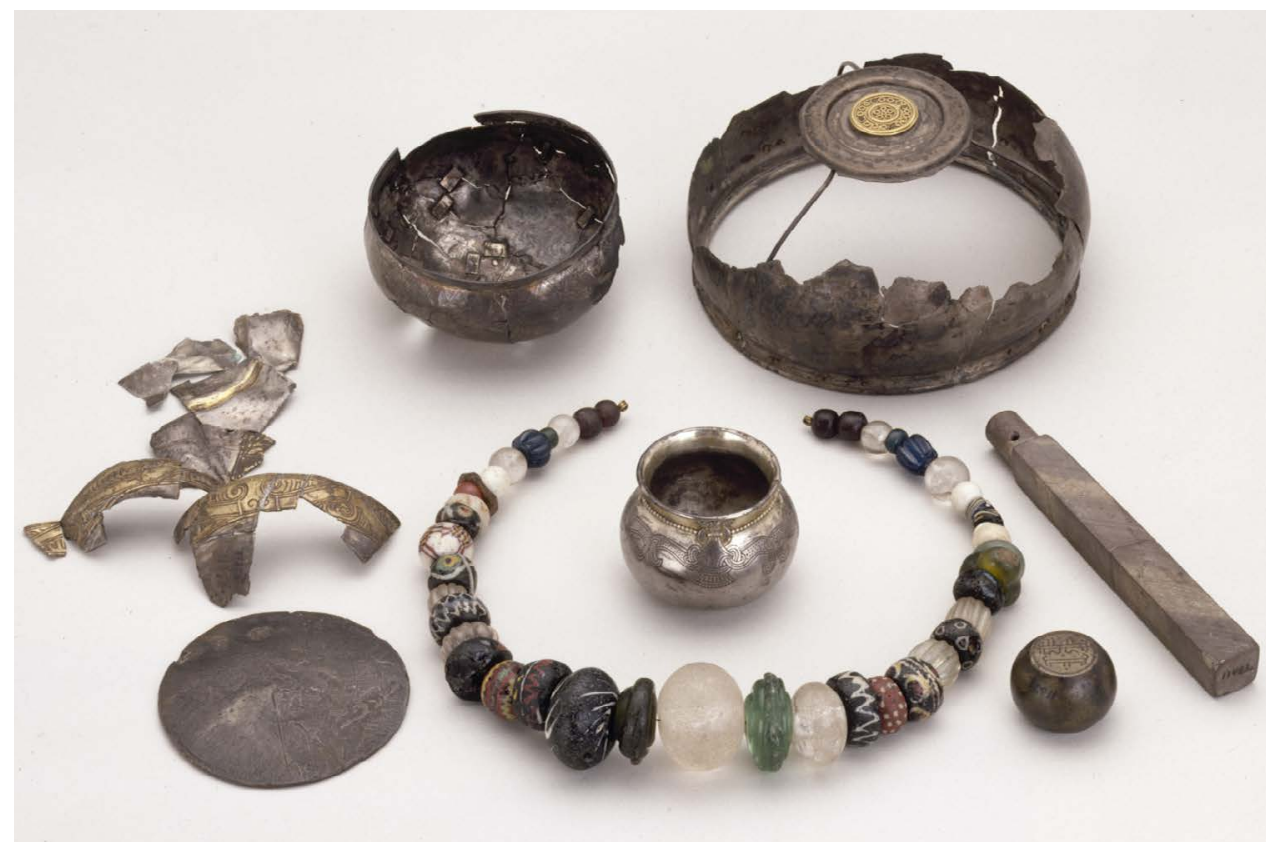

Figure 2. The Lejre hoard was excavated by amateurs in 1850, and contains several conspicuous objects. Furthest to the right is the banded schist, which might be part of ritual objects belonging to the Lejre dynasty. Photo: National Museum of Denmark. 


\section{Material and methods}

The so-called Lejre hoard is central to this study (see Fig. 2); it was found by amateurs in 1850 under such suspicious circumstances that it has been difficult to establish whether it was a grave or a deposit (Christensen 2010). Our study will also focus on an analysis of staff-like pendants found at Tissø. Both these find groups are important because they stem from loci classici related to the Viking Age South Scandinavian elite, but also because they provide significant new information about symbolism relating to whetstones.

Several objects in the Lejre hoard are exceptional: e.g. an $8^{\text {th }}$ century hanging bowl, a small silver cup decorated with four winged female figures, a cup in the Mammen style, and a silver plate. The bead finds contain a rare collection of highly coloured glass and stones. They also include a rectangular whetstone, with very regular surfaces and smooth edges. One of its ends is circular, presumably to fit in some kind of base, or means of suspension. A preliminary analysis of the banded schist it is made of suggests that it has a central Swedish provenance. The deposit of these items of varying age must have taken place c. AD 1000 , and coincides with the end of Lejre as a royal site. What the objects represent is difficult to determine but as a whole the assemblage corresponds to what later medieval chronicles and sagas would call a royal environment, befitting Lejre.

Our focus is on the $14 \mathrm{~cm}$ long Lejre whetstone, which has been mended with glue. It has a rectangular slightly rhombic cross-section with four flat surfaces. The cylindrical end has a perpendicular hole drilled through it. Since the cylindrical end sits slightly off-centre the hole is not parallel to the flat surfaces, but rather diagonal, meaning that if the object was hung, one of its edges would face out. ${ }^{2}$ The hole and the cylindrical end do not exhibit any obvious signs of wear, for instance from having been suspended, or any other kind of abrasion. However, the flat bottom - or top - on the cylindrical end has a small incision of a pentagon, which is an unusual shape for the Viking Age (see Fig. 3).

The stone used has a foliated (layered) structure, cut so that the bands run diagonally over the flat surfaces. The colours of the bands range from tan to dark brown, and they are more distinguishable when the stone is wet. The darkest bands appear to be the thinnest.

Originally the flat surfaces appear to have been

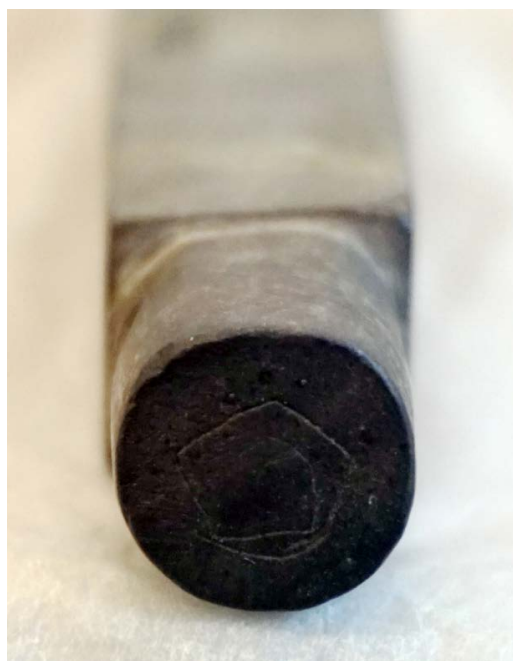
polished smooth, although now they are scratched. The cylindrical shape was probably achieved through filing, since narrow flat areas are discerni-

Figure 3. A pentagon is incised on the cylindrical end of the whetstone - a shape which is very unusual in Viking Age contexts. Its meaning remains unexplained, but it adds to the special character and symbolic relevance of the object. Photo: M. Taube. 
ble all around the circumference. The hole, which probably held a transverse rivet, is circular and appears to have been drilled from both sides, deduced through the x-radiograph. There is no obvious sign of use anywhere on the stone. As noted above, the flat surfaces are scratched, but mostly lengthwise, which does not correspond to what would be expected from an object used as a whetstone, or touchstone.

To determine whether the specimen had been used as a touchstone for identifying precious metal alloys (see below), an XRF analysis, with a Bruker Tracer 5G instrument, was performed with one-centimetre intervals. Two spectra were used in sequence: 1) at $40 \mathrm{kV}$, $7.4 \mu \mathrm{A}$ with the TiAl filter, which detects most elements, including transition metals; and 2) at $15 \mathrm{kV}, 15.05 \mu \mathrm{A}$, without a filter to detect light elements more readily, as well as low-energy peaks for silver and gold. The examination of the initial surface was performed in two parallel rows, and the other three only in one row.

One of the reasons for analysing the Lejre stone was the distinctive SEM-results presented by Martin Ježek on different types of whetstones, for instance from the boat burials at Vendel, Valsgärde, and the cemeteries at Hedeby, Birka, and elsewhere (Ježek 2013, 2014, 2016, 2017; Ježek and Holub 2014; Ježek and Hansen 2019). This research suggests that a surprisingly large portion - perhaps even a majority - of what previous archaeologists have determined to be whetstones found in graves, could in fact have been touchstones, or had dual uses. ${ }^{3}$ Several such stones found among - mainly - grave goods, and a few from settlements in Scandinavia and other parts of the Baltic Sea-area, have been analysed using scanning electron microscopes (SEMs). Such analyses have included more uniformly coloured types of schist, as well as the characteristically banded schist (e.g. seen in Lejre), or slate, and sandstone (Resi 2011). The analyses have revealed that several specimens display traces of precious metals (gold, silver), and other - non-ferrous - metals important to the smiths of the time (e.g. lead, brass, and zinc). Such results indicate that the various stone types were used for evaluating raw materials, presumably as part of trading, or in preparation for working the precious metals, alongside their use for honing weapons. However, some find contexts, such as graves, indicate that the interred would not have had any direct functional relationship to the stones. This can be established through the traits of the buried, e.g. when stones were buried with an infant (Ježek 2013: 716); or the social status of the interred suggesting that they were not metal workers (Ježek 2017: 79-80); or even displayed through the morphology of the stones themselves, as in specimens so large that it would have limited their practical use (2016: 492-3).

\section{Whetstone pendants from Tissø}

The staff-like pendants found at Tissø could perhaps be described as the morphologically simplest pendants of the period. They are little more than sticks of metal - only rarely with ornamentations - with forged loops, or flattened and perforated, so that they can be threaded onto a ring. Typically, the pendants were made of iron, but occasionally more precious metals, such as bronze or silver, were used. Their symbolic connotations have regularly been attributed to magic, such as the relationship to Óðinn, suggested by Birgit Arrhenius (Arrhenius 1961: 154), as part of a more general interpretation of amulets; or more specifically relating to seiðr and volur - as suggested by Neil Price, who argues that the small amulets are miniature versions of the large metal staffs of the volur (Gardeła 2016: 119; Price 2019: 166-8). However, the morphological features of these small pendants are noticeably similar to those 
of whetstones, and there is no morphological resemblance to the quite intricately designed volur staffs, which were made using elaborate production methods (Gardeła 2009: 203).

These small oblong pendants are often found in hoards, or graves. Tissø, on western Sjælland, provides an extraordinary opportunity to evaluate the distribution of this type of pendant, since all iron artefacts from the site - both detector finds and those stemming from excavation - have been collected and registered by the Danish National Museum. They now amount to c. 2,500 artefacts, and more than 500 pieces of slag of various kinds. This provides researchers with a material that can contribute to a broader understanding of the distribution of such finds at settlement sites in general, also including what the simpler iron specimens might have looked like. Finding small miniatures at the Tiss $\varnothing$ complex is a rather frequent phenomenon, the site has revealed more than 25 Pórr's hammers; 10 shield-shaped pendants; 15 anthropomorphic figures; as well as other artefacts that are more difficult to determine typologically, such as the staff-like pendants mentioned above. These objects are often made of iron, and found during ongoing metal-detector surveys.

So far, three separate finds - and a possible fourth (FG-1178) - have been classified as staff-like, and two of these share quite a few features (see Fig. 4), since both are made of iron with forged looped, or flattened perforated, heads. The object on the right in the figure, with a small piece of a ring still attached might be a ringed pin, but appears smaller, and when compared with the similar rings from Tissø, which include Pórr's hammers, it seems more

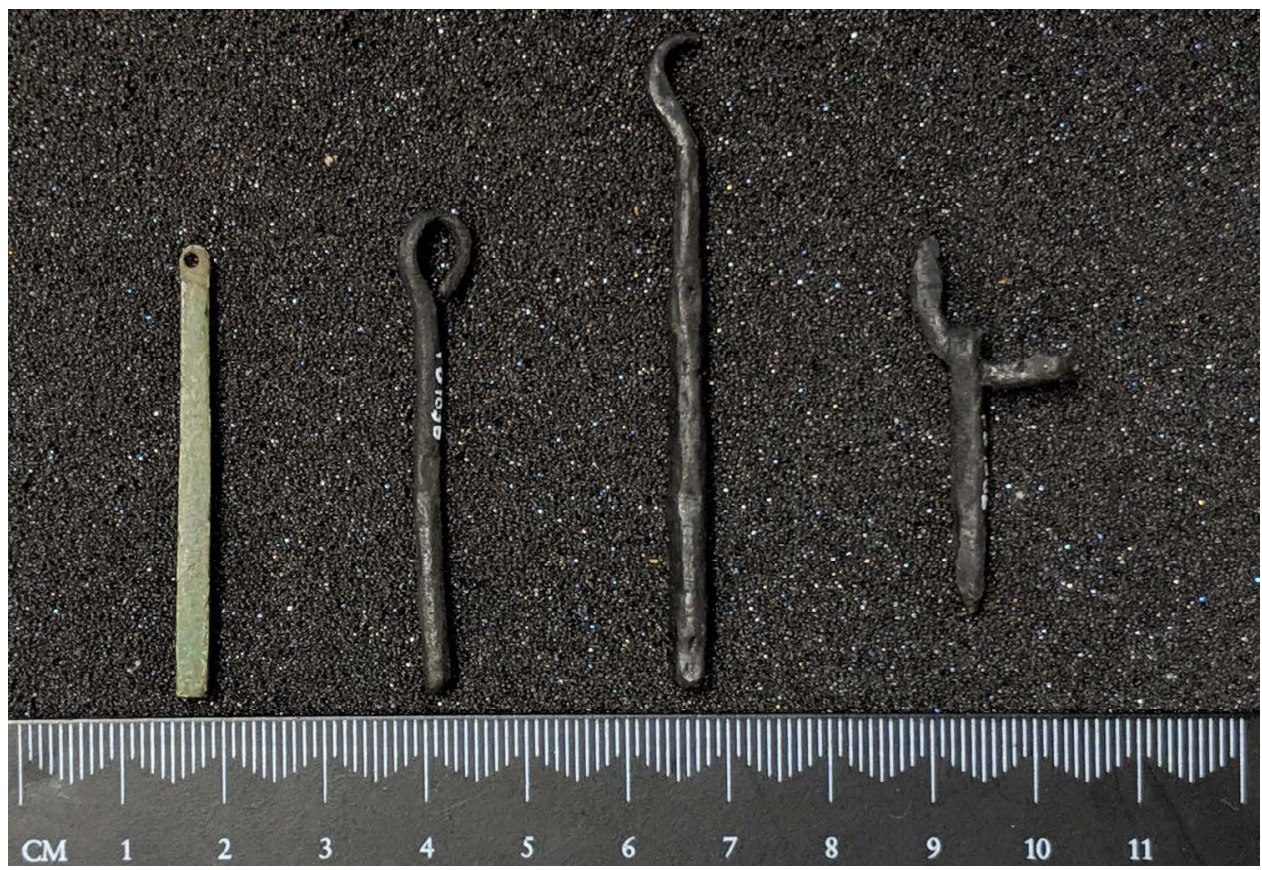

Figure 4. Four staff-like pendants (from the left FG-2104, FG-1638, FG-1178 [debatable], FG-1808) have been registered at the Fugledegård residence by the western bank of Lake Tissø, Denmark. Photo: M. D. Jessen. 


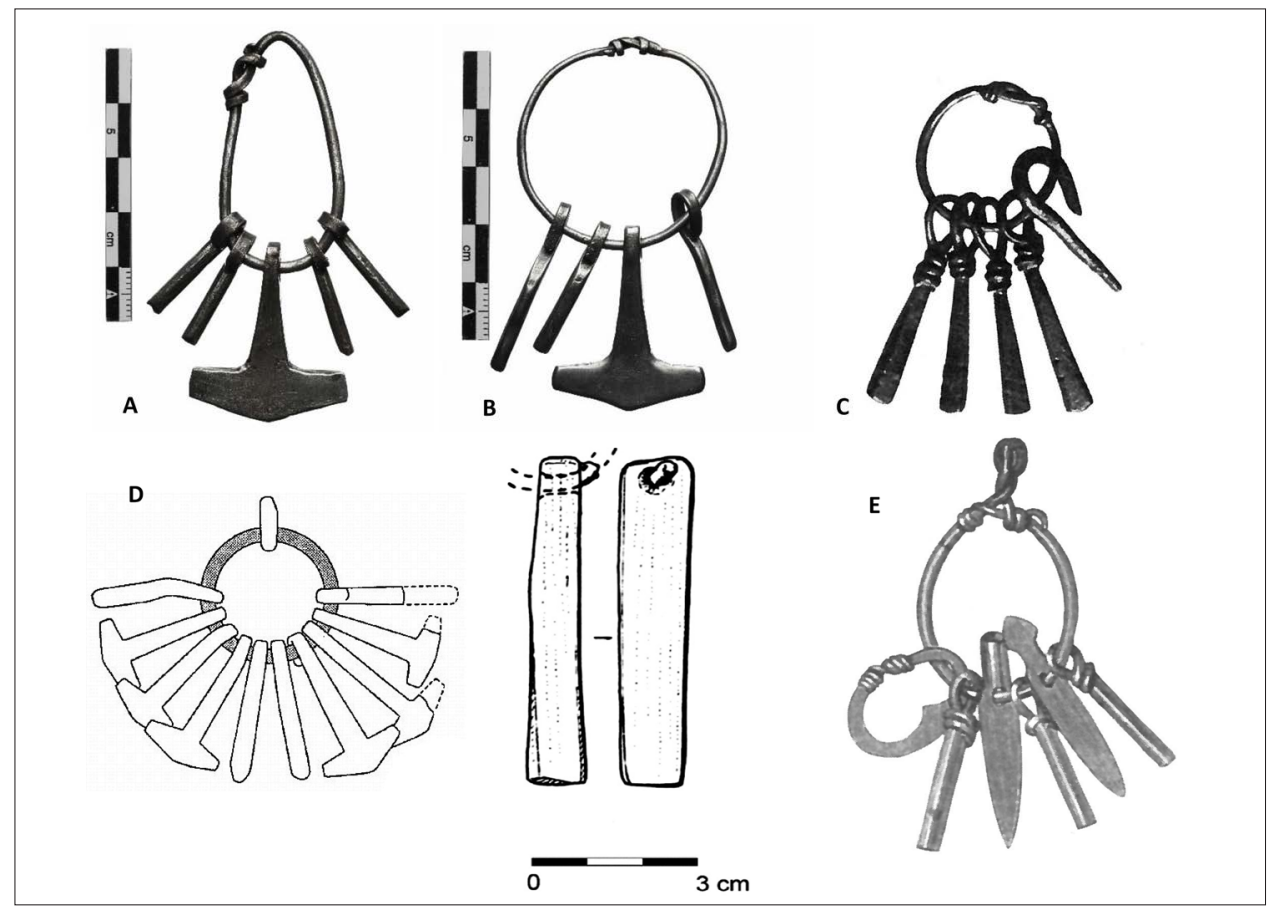

Figure 5. Examples of miniature pendants of iron, silver, and stone, A: Knudsker, B: Rømersdal, C: Kokemäki (not to scale), D: Thumby-Bienebek, grave 7, E: Klinta/Köping. Photos: A+B: National Museum of Denmark, C: after Price 2019: fig. 3. 106, D: after Müller-Wille 1976, abb. 5+7, E: Klinta/Köping after Arrhenius 1961, fig. 3.

valid to interpret it as a staff-like pendant. ${ }^{4}$ Since the ring is broken, there is a possibility that it held additional pendants, which are now lost.

The pendant on the left (FG-2104) differs significantly from the others, since it is made of bronze and is very regular in shape; it measures $4.4 \mathrm{~cm}$ in length and is $3 \times 3 \mathrm{~mm}$ at its widest, near the completely square end furthest from the hole. The hole end is slightly tapered, flattened and rounded. The pendant displays no signs of wear, and could therefore be unused. When considering the quite remarkable similarities to the Lejre stone a valid interpretation could be that this is a whetstone pendant. The morphological similarity is striking, and its slender and square appearance particularly resembles the design of such banded whetstones. We have not been able to identify any other bronze pendants of similar shape, although the small, rectangular pendants from Kokemäki (Fig. 5 C) are of a comparable design, and do - to some extent - resemble their whetstone counterparts more than the Tissø example does. In fact, in these cases the resemblance between whetstone and pendant is so striking that we propose that the similar and more numerous cylindrically shaped pendants should also be interpreted as miniature versions of whetstones. In many ways this small piece of semiprecious metal (FG-2104) could be understood as a 'missing link' between the larger, naturally sized whetstones, and the pendants of so-called staff-like shape. 


\section{Results}

The Lejre stone and XRF

If the Lejre stone had been used to test metal or ore, or to sharpen iron objects, it seems reasonable that a small amount of residue would remain on its surface, even after repeated use and cleaning, and hence we performed a systematic XRF examination of all the surfaces to reveal such traces. The analysis technique is very sensitive in the part of the spectrum where gold L-lines occur, as well as for the copper and zinc K-lines, however, no traces of gold, silver, zinc, tin, or copper, were detected during our analysis.

The stone itself is an iron-containing silicate (Fig. 6) with some possible carbonate layers, due to variations in the amount of calcium detected along the length of the object.
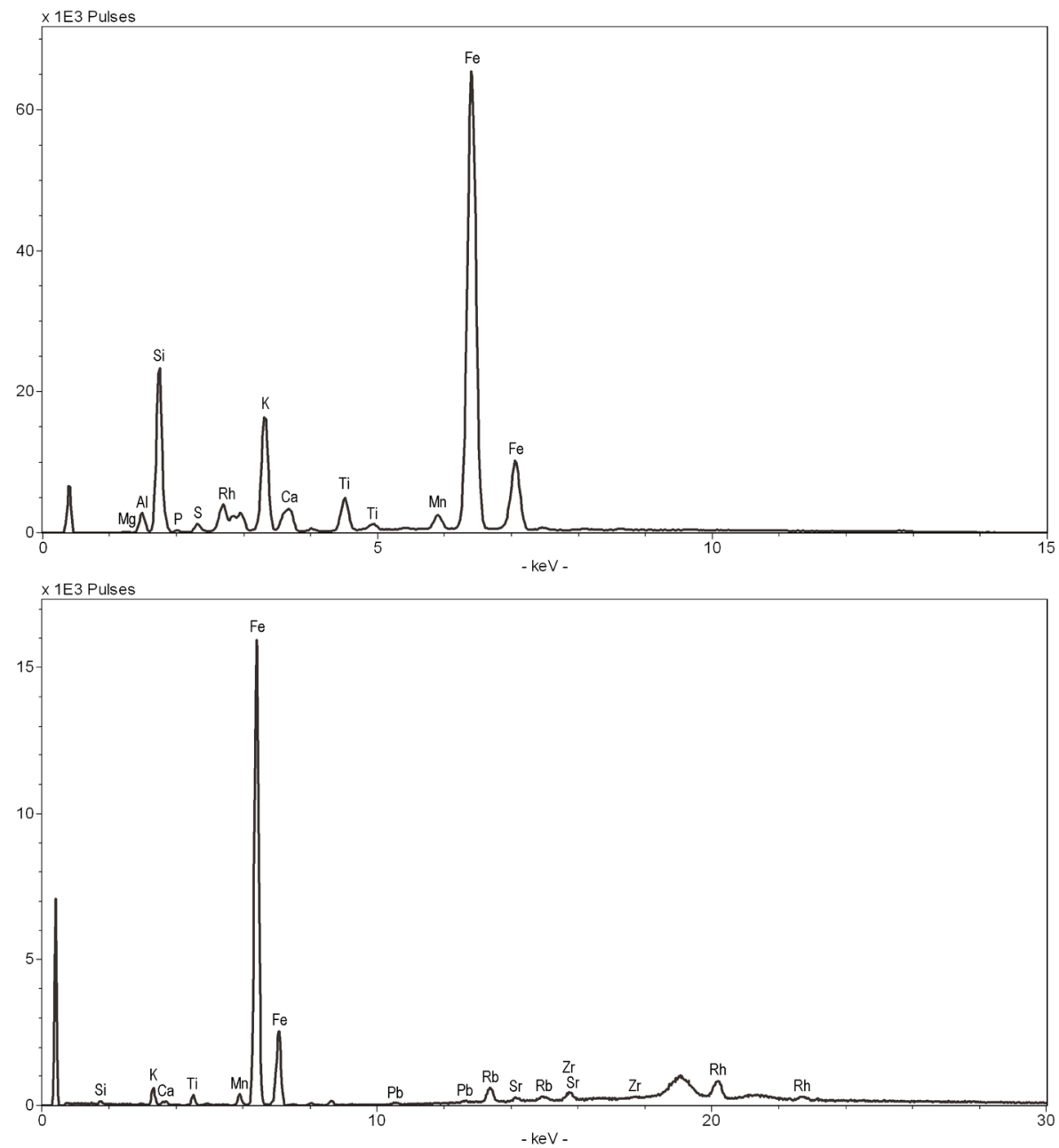

Figure 6. Representative XRF spectra of the Lejre stone (upper: taken at $15 \mathrm{kV}$, lower: at $40 \mathrm{kV}$ ). The XRF examination of the Lejre stone did not show any obvious signs of metal residue; the iron (Fe) peaks are attributed to iron content in the schist itself. Graphics: M. Taube. 
All in all, the stone seems to have seen little use, at least not any kind of use or wear that can be attributed to a specific type of activity. Since many stones naturally contain some amount of iron, the background spectrum of the stone itself made it difficult to determine whether there are any iron traces on the surface through the XRF examination. Furthermore, iron could also have been added - or removed - from the stone surfaces due to normal processes while it was buried. This means that potential honing remains - apart from those leaving visual traces of wear - were hard to detect.

The reason for the fracture near the middle of the stone cannot be determined, and could possibly have occurred during use, deposition, or as a result of weathering processes (such as frost), rough handling during retrieval, or in a museum accident.

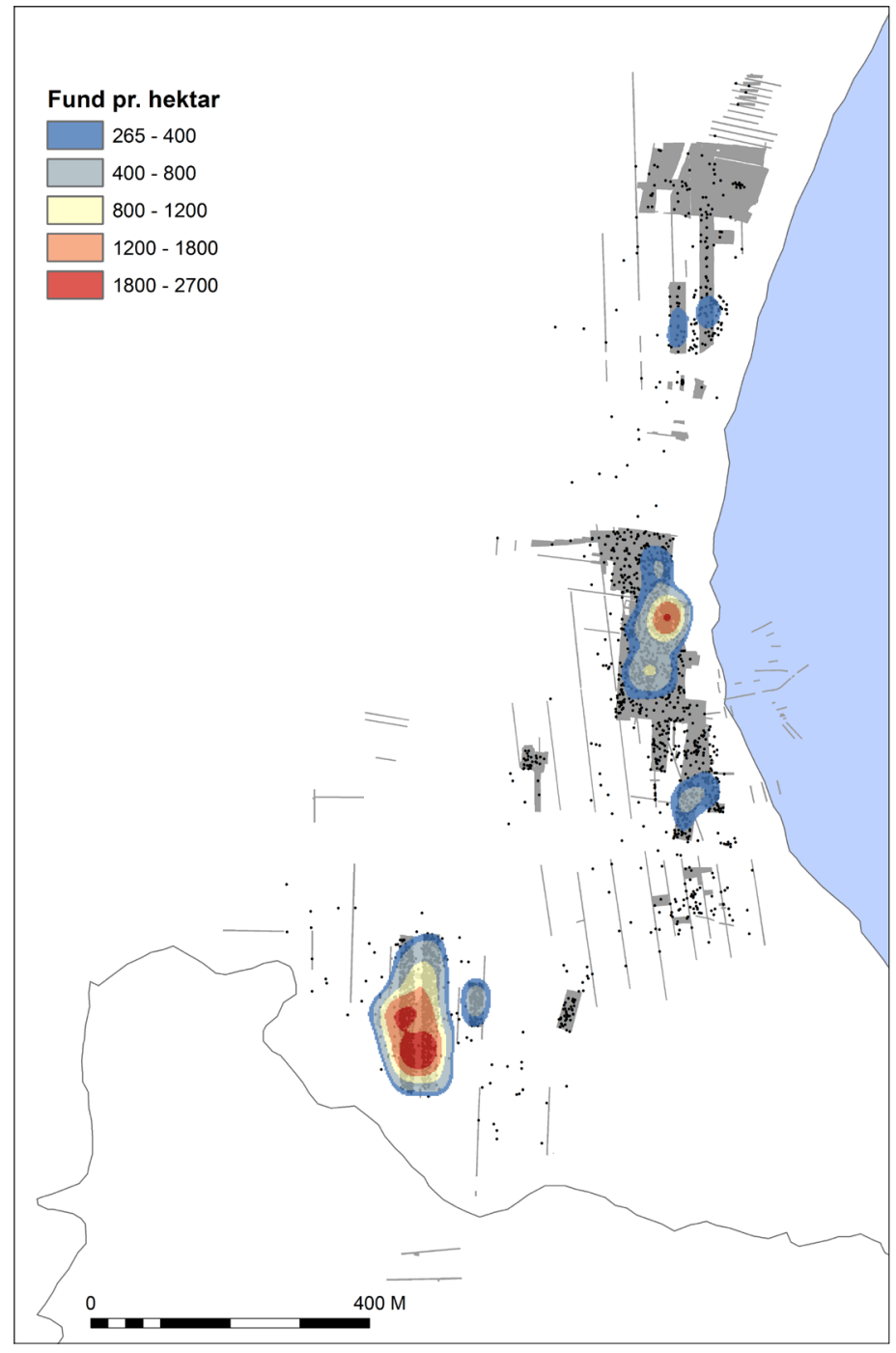

Figure 7. The density of metal and slag finds (a total of 4,710 finds) shows two distinct find clusters at Tissø. One to the south, at Kalmergården, and one further north, just inside the northern border of the Fugledegaird residence. Graphics: Pre-Christian Cult Sites / J. F. Bican. Reproduced with kind permission. 


\section{The Tissø finds}

The distribution of the Tissø finds reveals several interesting details about the overall metalcraft activity at the site. A complete map of the excavated areas, based on the combined density of iron objects and slag, mirrors the distribution of metal crafts, and reveals a few other things that deserve mentioning as well (see Fig. 7). During the earlier most northerly Bulbrogård phase (c. AD 575-700), iron and slag were virtually absent in comparison to the two later phases, at least in relation to the actual residential area. Kalmergården (c. AD 5751000) to the south, which can best be described as a chaotic 'palimpsest' of pit-houses and postholes, accounts for the majority of the iron and slag finds. In contrast to the Bulbrogård phase, the ensuing Fugledegård phase, from approximately AD 700-1000, has two clusters of metal finds, and both are situated inside the fences demarcating the residential area.

At Fugledegård, a northern two-phased cluster seems associated to the north-western corner of the residential area, and consists of a pit-house and a small building, presumably a smithy with an attached building (see Albris and Gotfredsen, forthcoming; Thomsen, forthcoming). This cluster also contains hammerscale, and traces of other metal-working activities. All four pendants were found here (see Fig. 8), and accordingly they can be associated to a production area at the Fugledegård residence, which was clearly under the control of the resident magnate. It is difficult to determine exactly what types of artefacts were produced here, but it seems clear that the area was dedicated to iron work. Several knives with steel inlays - one even pattern welded - found here are of very high quality, which is also the case with two swords and one spearhead deposited in the adjacent Lake Tissø. Interestingly, the iron - and possibly steel - bars that were found at the site seem to originate in Swedish Uppland (according to the metallurgical report by Arne Jouttijärvi). So, not only were the pendants found at a site where one would expect armaments to be produced but also in a part of the site (i.e. the demarcated residence) where the magnate in control of production resided; a person that may also have been responsible for mustering the army of the area.

Such connections - between the large magnate halls and smithies - are often overlooked. In the case of Järrestad, Skåne, Sweden, which virtually shares the physical layout of the Fugledegård residence (a large hall-building with a smaller enclosed building to the south), this link between 'ritual metallurgy' and aristocracy is even more pronounced, since the roof posts of a small, presumably ritual house inside the enclosure next to its hall, contain deliberate slag deposits, and in one case even a hammer (Söderberg 2003: 131; 2005: 233-6).

\section{Discussion}

Returning to the questions set out above: was the deposit of the Lejre whetstone a symbolic deed meant to discredit royalty, and/or did it simply symbolise authority over metallurgical processes and trade?

Albeit a speculative chain of thought, it is difficult to ignore that if the stone truly symbolised authority, the deposit of the very valuable items comprising the Lejre hoard, including the broken stone, could indicate a symbolic burial - or offering of items - connected with the discredited royalty residing at Lejre. The symbolic connotations almost seem too obvious; i.e. the power of the Lejre dynasty had been broken and buried, so the same should apply to their items of authority. Similar burials of ritually and/or authoritatively important objects also took place at Uppåkra, Gudme, and Birka. At the former site, an elaborate glass 


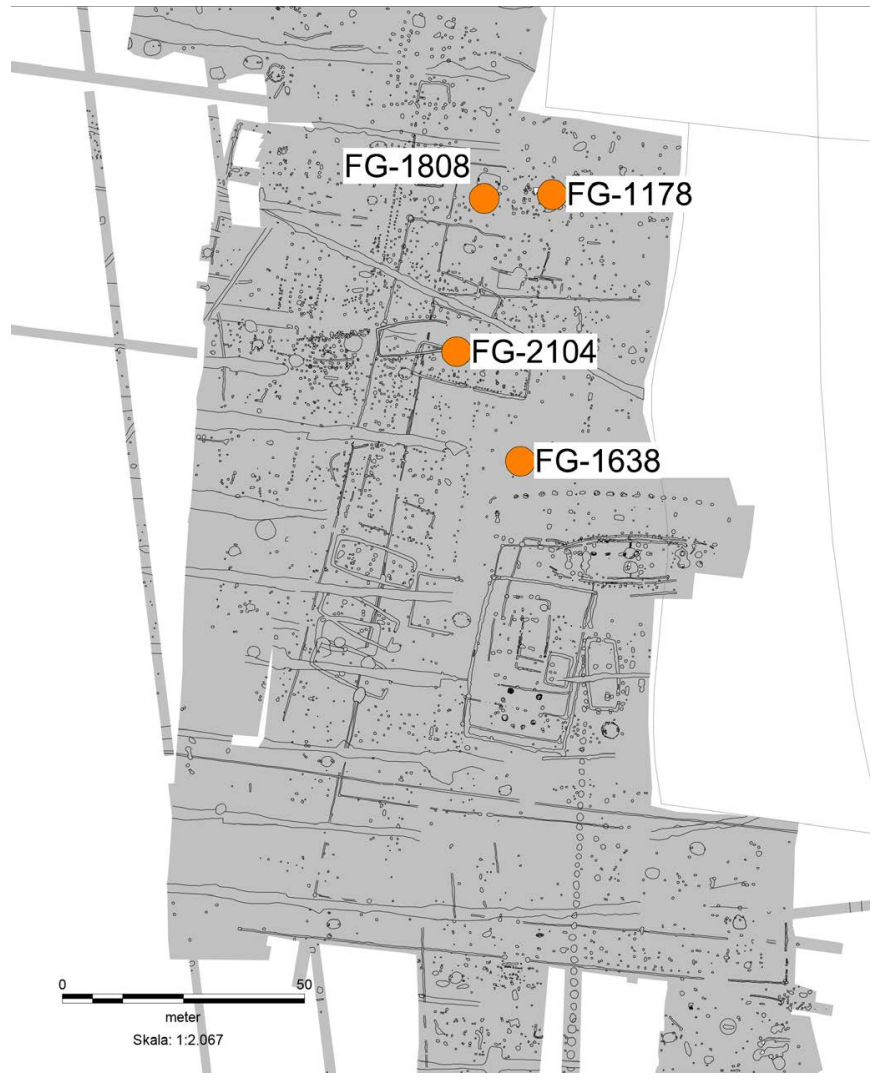

Figure 8. All of the three - possibly four - rod pendants were found in the northern metal find cluster inside the northwestern part of the fenced area around the Fugledegård residence. Graphics: Pre-Christian Cult Sites / J. F. Bican. Reproduced with kind permission.

bowl, and a silver vessel seem to have been deliberately destroyed and covered with the clay-floor layer of a new building, which was built on top of a former burnt-down building (Larsson and Lenntorp 2004: 24). At Gudme, a large pit (A556) seemingly contained the remains of equipment belonging to a late Roman Iron Age building, House III (interpreted as a possible temple structure), where unusual objects such as fragments of a carriage, weapons, and a metal vessel were found together with a substantial amount of pottery, a bull figurine, and other objects. Many of these deposited artefacts seem to have had a life-span of 150 years, or more (Sørensen, forthcoming), which could indicate a deliberate simultaneous burial of all the equipment belonging to the house. Finally, at a hall building in the area called Garnisonen at Birka, as the feature A9 was excavated, several deposited artefacts, including three whetstones (of schist and sandstone), were found. That these were deposited alongside spearheads, knives, a ferrule, Pórr's hammers, armament fragments, and several other objects, as well as the vast amount of weaponry excavated in and around the building, implies martial connotations (Hedenstierna-Jonson, Åhfeldt and Stjerna 1998; Holmquist and Åhfeldt 2002), and it has been argued that the deposit could refer specifically to Óðinn and his role as the warrior god of the aristocracy (Kitzler 2000: 18-9).

A similar interpretation may be applicable to the Lejre hoard and the aristocratic milieu it seemingly belonged to. The excavating archaeologist Tom Christensen suggests that the 
hoard was deposited during the decade around the year AD 1000, and that it marked the end of a long tradition of Lejre as a royal hall settlement. He also noted that the last hall even had a male burial in the middle of the main room (Christensen 2010: 186; Christensen 2015: 93). Could the Lejre hoard be linked to the end of this tradition? If that were the case, who then compiled and deposited the hoard? It could either have been the new rulers of the area perhaps as a symbolic ritual 'burial' of the Lejre dynasty - or the old lineage performing a last gesture of veneration.

In connection with forging tools found in several Swedish burials, Ježek introduces a useful term, 'ritual metallurgy' (2016: 501). The term implies that the inclusion of forging tools, whetstones, or touchstones in aristocratic burial assemblages, does not necessarily indicate that the interred was a smith by trade but that they were placed there for ritual and symbolic reasons, and reflects a classic archaeological interpretation problem regarding grave goods (Stöllner 2007). For that reason:

The presence or absence of these symbols [i.e. touchstones/whetstones] in the grave inventory reveals nothing about the activities of the deceased while they were still alive. Gender or age aspects play no role in the Early Middle Ages in this case. The symbolic behaviour of the bereaved had much deeper motivation (Ježek and Hansen 2019: 3433).

We would agree to some extent, but a symbol rarely has no relevance, and in the investigated period it would be fair to expect that the symbols referred to the livelihood of the interred, or at least to a more overarching influence over the use of such grave goods, with connotations to smiths and their products. A good example of the symbolic character of the whet- and touchstones can be seen in the metals detected on some of the stones; since metals such as zinc ${ }^{5}$, or tin are rare but not necessarily precious, the ritual implications of providing the deceased with small amounts of such metals does not seem to be related to the value of the metals. It was more likely meant as a symbolic reference to the process of detecting specific metals, but perhaps also to their evaluation and their trade. These would be connected to privileges and obligations of the deceased, such as control over the production and the products of metalworking, or the trade of such goods, as well as the access to, and distribution of precious metals. In that case, the grave goods could refer to someone with control over turning raw material into weapons, and of the stones that hone them, as well as the stones that can monitor the value of non-ferrous metals. In such a scenario the grave goods become symbolic extensions of the entire metal-working process - ferrous and non-ferrous. However, the concept of 'ritual metallurgy' does not seem to end with the placing of forging tools and bars of banded schist in burials. Therefore, we will turn to the pendants and miniatures that have been found in several burials and deposits, and specifically to the so-called staff-like pendants, their possible connection to smiths, and consequently their relationship to local magnates.

\section{Aristocratic relationship to smiths?}

The examples above that link metalworking and aristocratic settlements are by no means arbitrary, and emphasise the special position that craftspeople held in post-Roman Northern Europe. In this era the establishment and maintenance of the authority depended - to a large degree - on skilled metalworkers, since lordly positions relied heavily on reciprocal gift giving (Wright 2019: 273; for the preceding periods see Carnap-Bornheim 2001). In other words, the control over elite smiths - and their precious products - was extremely important 
for expressing loyalty both within aristocratic strata, and between them and their vassals (Hedeager 2002: 10; Birch 2011: 12-5). At the same time, the transformation of raw materials into beautiful objects seems to have been enveloped in a distinct aura of danger and suspicion, endowing smiths with liminal qualities (Wright 2019: 272). Hrungnir's battle against Pórr is perhaps an expression of this liminal duality, and can be seen as a battle between stone/whetstone and iron/hammer (i.e. the tools of the smith), and their symbolism, interpreted by Schjødt (2008: 237, note 22), as a conflict between the uncivilized and the civilized, chaos and cosmos, or even between nature and culture. The clash between iron and stone also has a symbolic link to fire making, and to the transformative powers of the smith, who controls and uses fire, essential to his magical and supernatural abilities (Kuusela 2016: 58-62). ${ }^{6}$ These hybrid metal-working characters and their produce - so important for the influence of the aristocracy, but still enigmatic and threatening - nonetheless operated under the auspices of their patrons but always at a safe distance. This peripheral but still controlled placement of the smithies is discernible in the physical layout of the Fugledegård residence where the area is situated still visible $-80 \mathrm{~m}$ from the main hall - in the extreme northern end of the fenced residential area.

The archaeological record suggests that several new types of miniature pendants were introduced in the early $9^{\text {th }}$ century (Jensen 2010: 58-60). Contrary to the elaborate ornamentation otherwise found on Viking Age objects, these pendants are morphologically recognisable as miniature artefacts, instead playing with material and size. They can almost be seen as 'iconic' miniatures due to their similarities to their full-sized counterparts. So, as part of the diffusion within whetstone symbolism, downscaling is also added. This contributes even more to the ambiguous boundary between the authoritarian manager (i.e. the patron) and the actual producer (the craftsman). The overall emphasis of metalworking still seems to rest on the production of iron goods, and the control and distribution of raw materials, where cultural practices and processes become symbols of a shared societal organisation. Just as in the case of the smiths' graves at Valsgärde, as discussed by Ježek and Hansen above, where the tools do not necessarily represent a craft but instead someone's authority over craftsmen and their related products, this detachment seems to have impacted the material anchoring of the miniature objects as well. As they were transformed into symbols the actual use of the original object became unimportant, and fundamental sensory-motor affordances of the stones were cast aside. This enabled the use of diverse materials, as well as an almost playful experimentation with size. Accordingly, in this 'ritualised metallurgy' these subtle symbolic miniaturised oblong ring-mounted objects appear almost 'out of context'. Thus, the morphology of the whetstone shapes almost takes on a fractal reappearance across materials where the proportional considerations are neglected in favour of a symbolic reference to the distant originals (Whitridge 2016). However, when an object is downscaled - or up-scaled - its original application is also subject to change.

This becomes even more evident when the original material, schist/slate/sandstone, is substituted by metals - such as iron or bronze - that cannot even perform the same tasks as the original stones - neither evaluate precious metals nor hone swords. This implies that the pendants were intended to create non-natural concepts, as the practical connotation between pendant and stone is virtually absent. Certain aspects of it may resemble a whetstone, but it is no longer an object intended for honing, and it has become something other than a whetstone. What is left is a symbolic abstraction from full-size original artefact to miniature, and 
in this case one could rather speak of a 'simulation' of a whetstone. Evidently, the pendants represent an abstracted understanding of the original object, and the configuration and shape of the pendants are based on morphological suggestions, and not necessarily on any kind of definite functionality (Knappett 2012: 92). As already mentioned, whetstones are recurring features of graves, hoards, and settlement find assemblages from the Scandinavian Late Iron Age and Early Middle Ages, as well as important trade goods during the period. Such finds often differ from the conspicuous Sutton Hoo example mentioned above. They come in various shapes and sizes, and may appear as ordinary tools, or as more elaborate, almost ornamental, specimens (see for example grave 85 at Starigard/Oldenburg in Gabriel and Kempke 2011, which contained a specimen attached via a cord embroidered with gold). The ambiguous connection between pendants and stones is also visible through their co-occurrence in graves. One example comes from grave 7 at Thumby-Bienebek, where four similarly shaped $4 \mathrm{~cm}$ long iron rods were found on a small ring along with several Pórr's hammers, in the same burial assemblage as an actual whetstone (Müller-Wille 1976: 50-1) (Fig. 5 D). When they appear in the same archaeological contexts, the physical similarities might also reflect a wish to strengthen the ties between functional and symbolic objects. The co-occurrence of miniature Pórr's hammers and these proposed whetstones pendants is not unusual either; the large Rømersdal silver hoard, as well as the one from Knudsker, Bornholm (see Fig. 5 A+B) both had silver rings with rods and hammers placed together (contrary to Price 2019: 68). This recalls the aforementioned description in Haustlong where such full-sized objects are used as weapons in a fight between giant and god, perhaps related to through the two types of miniature pendants, or at least referring to the importance of controlling metalwork. Accordingly, the difference between the actual object and the symbolic version that it refers to, is at times very hard to define, and that might be a reason for the pendant being an actual object in itself, although only as a miniaturised symbolic proxy. Therefore, this might be a testimony to a continuing abstraction of the ideal shape of a whetstone, such as the ones directly connected to magnate rulers expected in places like Sutton Hoo and Lejre, leading to - mostly later - versions where the connections to idealised kings have become symbolic, and perhaps to some extent even forgotten. Consequently, what is distinguishable in the whetstone pendants from the late Viking Age might be a diffused version of the concept of - for lack of a better term - 'Royal Whetstones', originating in the Migration period. A diffusion that rested on a hierarchical chain of social references, where the upper echelon of society made use of particular (and perhaps even peculiar) artefacts, such as whetstones, to emphasise their positions. Over time, the 'material concept' spread to lower societal strata, and a more communal system of representations, which might, as a counter-effect to their aristocratic counterparts, even have had a democratising effect where their size, ease of manufacture, and simple materials made them conduits for social action on a more general level (Meskell 2015: 10). Importantly, the miniatures not only referred to a distant past or life-size proportion (contrary to the ideas of Kiernan 2015), but had a real place in the life of Viking Age Scandinavia, where they were part of the contemporary symbolic world.

A delicate silver ring with pendants, from a lavish female grave in Klinta/Köping on Öland (Schulze 1987: 55-7), could perhaps provide a more concrete example of the contemporary symbolic use of the proposed whetstone pendants, and what they could bestow (Fig. $5 \mathrm{E}$ ). The items on the ring are miniatures of a strike-a-light, a spear, a sword, and three iron rods - supposedly whetstone pendants. In many ways the ring and its miniatures summarise 
the requirements for producing, and the actual production of full-size weapons; the strike-alight for waking the fire used to smelt the ore into malleable iron that could be shaped into different kinds of weapons, like swords and spears. The whetstone completes the process by honing the weapons so that they are ready for battle. The ring, and its circle, could symbolise a circle of transformation, describing the transition from raw material - bog iron - to a finished product, and also allude to the possible trade of that product to acquire the valuable materials - such as silver - that the metal ring and pendants are made of.

In this respect, it is interesting that one of the three lead seals of Patrikios Theodosius Baboutzikos (AD 840/1) that have been found in South Scandinavia was excavated at Tissø (the other two at Hedeby and Ribe). Theodosius was a high-ranking Byzantine official stationed in Venice, who was charged with strengthening the city's troops for the fight against the Arabs. He travelled to the court of the Frankish emperor to seek help, and his main task was to collect war equipment (McCormick 2007: 52-3). The combined finds of the proposed whetstone pendants, weapon fragments, and the abundance of iron and slag fragments at the Fugledegård residence, and more frequently at Kalmergården (in total more than $100 \mathrm{~kg}$ ) emphasise the site's affiliation to both ferrous and non-ferrous metal production. In such a context it is not surprising to find Theodosius' seal at Tissø, and it could serve as a confirmation of its involvement in weapons production, or at least in the trade of such goods - why else would Theodosius have pursued a connection to Tissø?

\section{Conclusion}

Viking Age pendants and their use have been subject to many years of research but the meaning of these miniature objects is still elusive. This also applies to the small rod pendants studied in this article. However, through their physical similarities to ordinary whetstones, and their regular contextual association with miniature weapons, strike-a-lights, and Pórr's hammers, we believe that they can be interpreted as miniature whetstones. A more specific affiliation, metonymically suggested by the function of the actual stones - the final honing of weapons - must be considered to be of central symbolic importance, and would also explain their collation with other miniatures - mainly representations of weapons - on rings. One reason for the appearance of these symbolic miniature whetstones could be that their life-size whetstone counterparts served as symbols of kingship, relating to rulers as warlords and providers of arms. In addition, a possible Odinic link bestows them with a sacred quality, especially in the cases of the remarkable Sutton Hoo whetstone, and the Lejre hoard stone. The latter was found with other high-status objects, which suggests a connection to the Lejre dynasty, and perhaps even its late Viking Age demise. In a more abstract interpretation of the symbolism of these stones, the possibility that they had additional uses as touchstones, links them to both weapon use, and various types of metal trade. Hence, the whetstone's symbolism alludes both to the original use of the stones, honing, but also to the detection of adulteration of precious metals. As such the stones could serve both as royal insignias and as instruments by which the elite maintained their wealth, through their supervision of production sites and mercantile affairs. 


\section{Acknowledgement}

Funding for this research was provided by the A. P. Møller Foundation (Grant APM j.nr. 102929). The funder had no role in study design, data collection and analysis, decision to publish, or preparation of the manuscript. The authors wish to thank Josefine F. Bican for helpful suggestions regarding the Tissø find material.

\section{Notes}

1 Placing a stag figure atop the stone, has been argued to be a reference to royal authority, due to the name Heorot (Old English 'hart', stag), appearing in Beowulf and denoting the large banqueting hall of the Danish Lejre King (Hicks 1978: 382).

2 Not many whetstones have a rebated tapering with a drilled hole, but similar finds have been made at Svarta Jorden at Birka, Sweden (Arrhenius 1973), and at the Viking settlement at Llanbedrgoch, Wales (Redknap 2006). The latter is even recessed at one end to accommodate a still preserved copper alloy ferrule. The ferrule has a striking resemblance to a helmet with nose-guard.

3 A touchstone is a small tablet of dark stone, such as slate or lydite, used for assaying precious metal alloys. It has a finely grained surface where soft metals leave visible traces when tested. The colour of the trace determines the purity of the metal.

4 The small flat example FG-1808 does have some resemblance to two rings with pendants (finds F30 and F37) from the site Lilla Ullevi, Uppland (Bäck, Stenholm \& Ljung 2009: 43-4). The excavators interpreted the metal rods on these rings as small nails used for hammering the rings into, e.g. a door, posts or other wooden objects. Similarly, Olof Sundqvist has suggested a relationship between rings and cult buildings connected to ritualised oath taking and/or other judicial acts (Sundqvist 2007: 179).

5 Zinc is special since the reduction from zinc ore to pure metal is difficult. Hence, the occurrence of zinc on the touchstones could be related to the evaluation of the raw ore and not the pure metal.

6 Kuusela argues that, due to its transformative capabilities, fire had a ritual function during the Viking Age, and in earlier periods.

\section{Bibliography}

Albris, Sofie L, Anne Birgitte Gotfredsen

Forthcoming A special production and activity area in the northern part of the Fugledegård residence at Tissø. In Pre-Christian Cult Sites, Tissø vol. 1: Landscape, buildings and organisation, edited by J. F. Bican, M. D. Jessen \& L. Jørgensen. Publications from the National Museum, Copenhagen.

Arrhenius, Birgit

1961 Vikingatida miniatyrer. Tor 1961: 139-64.

1973 Recension: Rupert Bruce-Mitford, The Sutton Hoo Ship-burial. A handbook published by the Trustees of the British Museum, London. Fornvännen, vol. 48: 68-9.

Baug, Irene, Dagfinn Skre, Tom Heldal and Øystein J. Jansen

2019 The Beginning of the Viking Age in the West. Journal of Maritime Archaeology volume 14: 43-80.

Birch, Thomas

2011 Living on the edge: making and moving iron from the 'outside' in Anglo-Saxon England. Landscape History 32: 1: 5-23.

Bäck, Mathias, Ann-Mari Hållans Stenholm and Jan-Åke Ljung

2008 Lilla Ullevi-historien om det fridlysta rummet Vendeltida helgedom, medeltida by och 1600-talsgård Uppland, Bro socken, Klöv och Lilla Ullevi 1:5, Jursta 3:3, RÄ̈ 145. rapport 2008: 39, UV Mitt, Riksantikvarieämbetet.

Bruce-Mitford, Rupert

1978 The Sutton Hoo ship-burial, volume 2, arms, armour and regalia. British Museum Publications, London. 
von Carnap-Bornheim, Claus

2001 The social position of the Germanic goldsmith A.D. 0-500. In Roman Gold and the Development of the Early Germanic Kingdoms: aspects of technical, socio-political, socio-economic, artistic and intellectual development, A.D. 1-550, edited by B. Magnus, pp. 263-78. Almqvist \& Wiksell International, Stockholm.

Christensen, Tom

2010 Lejreskatten. In Danefee. Skatte fra den danske muld, edited by M. Andersen and P. O. Nielsen, pp. 183-6. Gyldendal, Copenhagen.

2015 Lejre bag myten. De arkceologiske udgravninger. Jysk Arkæologisk Selskab, Højbjerg.

Enright, Michael J

1983 The Sutton Hoo Whetstone Sceptre: A Study in Iconography and Cultural Milieu. Anglo-Saxon England 11, 119-34.

2006 The Sutton Hoo Sceptre and the Roots of Celtic Kingship Theory. Four Courts Press, Portland.

Estham, Inger, Axel Unnerbäck and Herman Bengtsson

2010 Uppsala domkyrka, del 5. Inredning och inventarier. Sveriges Kyrkor 231. Upplandsmuseet. Uppsala.

Faulkes, Anthony

1998 Edda. Skáldskaparmál. Viking Society for Northern Research, University College London, London.

Gabriel, Ingo and Torsten Kempke

2011 Starigard/Oldenburg. Hauptburg der Slawen in Wagrien, vol. VI. Die Grabfunde. Einführung und archäologisches Material. Offa-Bücher bd. 85. Neumünster.

Gardeła, Leszek

2009 A Biography of the Seiðr-Staffs. Towards an Archaeology of Emotions. In Between Paganism and Christianity in the North, edited by L. P. Słupecki and J. Morawiec, pp. 190-219. Rzeszów University, Rzeszów.

2016 (Magic) Staffs in the Viking Age. Fassbaender, Wien.

Hauck, Karl

1954 Halsring und Ahnenstab als herrscherliche Würdezeichen. In Herrschaftszeichen und

Staatssymbolik: Beiträge zu ihrer vom dritten bis zum sechzehnten Jahrhundert. Monumenta

Germaniae Histórica, 13, edited by P. E. Schramm, pp. 145-80. Hiersmann, Stuttgart.

Hedeager, Lotte

2000 Scandinavian 'central places' in a cosmological setting. In Central Places in the Migration and Merovingian Periods. Papers from the 52nd Sachsensymposium, Lund, August 2001.

Uppåkrastudier 6, edited by B. Hårdh and L. Larson, pp. 3-18. Almqvist \& Wiksell International, Stockholm.

Hedenstierna-Jonson, Charlotte, Laila Kitzler Åhfeldt and Niklas Stjerna

1998 Garnisonen II: arkeologisk undersökning 1998: Uppland, Adelsö socken, Björkö. RÄ̈ 35. Arkeologiska Forskningslaboratoriet, Stockholms Universitet, Stockholm.

Hick, Carola

1978 A note on the provenance of the Sutton Hoo stag (Appendix A), In The Sutton Hoo ship-burial, volume 2, arms, armour and regalia, edited by R. Bruce-Mitford, pp. 378-82. British Museum Publications, London.

Holmquist, Lena and Laila Kitzler Åhfeldt

2002 Krigarnas Hus: Arkeologisk undersökning av ett hallhus i Birkas Garnison. RAÄ 35, Björkö, Adelsö sn, Uppland 1998-2000. Borgar och befästningsverk i Mellansverige 400-1100 e. Kr. 4.

Jensen, Bo Arkeologiska Forskningslaboratoriet, Stockholms Universitet, Stockholm.

2010 Viking Age Amulets in Scandinavia and Western Europe. BAR International Series, 2169. Archaeopress, Oxford.

Ježek, Martin

2013 Touchstones of archaeology. Journal of Anthropological Archaeology 32: 713-31.

2014 Touchstones from early medieval burials in Tuna in Alsike, Sweden. Journal of Archaeological Science 42: 422-9.

2016 Functional, symbolic or ritual? On several tools from the furnishing of aristocratic burials in eponymous Vendel, Sweden. Archaeological and Anthropological Sciences 8: 491-504. 
2017 Archaeology of touchstones: An introduction based on finds from Birka, Sweden. Sidestone Press, Leiden.

Ježek, Martin and Holub Milan

2014 Touchstones and mercury at Hedeby. Praehistorische Zeitschrift 89: 193-204.

Ježek, Martin and Sigrid Cecilie Juel Hansen

2019 Symbols missing a cause: the testimony of touchstones from Viking Age Iceland. Archaeological and Anthropological Sciences 11: 3423-34.

Jónsson, Finnur

1907 Edda Snorra Sturlusonar. Sigurður Kristjánsson, Reykjavik.

Kiernan, Philip

2015 Miniature objects as representations of realia. World Archaeology 47 (1): 45-59.

Kitzler, Laila Åhfeldt

2000 Odensymbolik i Birkas garnison. Fornvännen 95: 13-21.

Knappett, Carl

2012 Meaning in miniature: semiotic networks in material culture. In Excavating the Mind: Crosssections through culture, cognition and materiality, edited by N. N. Johannsen, M. D. Jessen and H.

Kuusela, Tommy J. Jensen, pp. 87-109. Aarhus University Press, Aarhus.

2016 Tors strid mot Hrungner: Tvekamp, brynstenssymbolik och krigarideologi. In Krig och fred $i$ vendel- och vikingatida traditioner, edited by H. Rydving and S. Olsson, pp. 47-90. Stockholm University Press, Stockholm.

Larsson, Lars and Karl-Magnus Lenntorp

2004 The Enigmatic House. In Continuity for Centuries: A Ceremonial Building and its Context at Uppåkra, Southern Sweden. Acta Archaeologica Lundensia, Series in $8^{\circ}$, vol. 48, edited by L. Larsson, pp. 3-48. Almqvist \& Wiksell International, Stockholm.

Lauring Palle

1979 Danmarks konger. Lindhardt og Ringhoff, Copenhagen.

McCormick, Michael

2007 Where do trading towns come from? In Post-Roman Towns: Trade and Settlement in Europe and Byzantium, (Millennium Studies 5), edited by J. Henning, pp. 41-68. De Gruyter, Berlin.

Mees, Bernard

2015 Work Songs and Whetstones: From Sutton Hoo to Straum. Scandinavian Studies 87 (4): 514-30.

Meskell, Lynn

2015 A society of things: animal figurines and material scales at Neolithic Çatalhöyük. World Archaeology 47 (1): 6-19.

Mitchell, Stephen A

1985 The whetstone as symbol of authority in old English and old Norse. Scandinavian Studies 57 (1): $1-31$.

Mitchell, J. G, Helge Askvik and Heid G. Resi

1984 Potassium-argon ages of schist honestones from the viking age sites at Kaupang (Norway), Aggersborg (Denmark), Hedeby (West Germany) and Wolin (Poland), and their archaeological implications. Journal of Archaeological Science 11 (2): 171-6.

Montelius, Oscar

1872 Sveriges Forntid. P. A. Nordstedt \& söners förlag, Stockholm.

Mortimer, Paul

2013 Michael J. Enright's 'The Sutton Hoo Sceptre and the Roots of Celtic Kingship Theory': a Critique. In Remaking the Sutton Hoo Stone: The Ansell-Roper Replica and its Context, edited by P. Mortimer and S. Pollington, pp. 78-93. Anglo-Saxon Books, Ely.

Müller-Wille, Michael

1976 Das wikingerzeitliche Gräberfeld von Thumby-Bienebek (Kr. Rendsburg-Eckernförde). Teil I. (Offa-Bücher 36). K. Wachholz, Neumünster.

Nygaard, Simon

2016 Sacral rulers in pre-Christian Scandinavia: The possibilities of typological comparisons within the paradigm of cultural evolution. Temenos 52 (1): 9-35. 
Pedersen, Anne

2014 Dead Warriors in Living Memory: A Study of Weapon and Equestrian Burials in Viking-Age Denmark, AD 800-1000. Publications from the National Museum, Studies in Archaeology \&

Price, Neil History, Copenhagen.

2019 The Viking Way: Magic and Mind in the Late Iron Age Scandinavia. Oxbow, Oxford.

Price, Neil and Paul Mortimer

2014 An Eye for Odin? Divine Role-Playing in the Age of Sutton Hoo. European Journal of Archaeology 17 (3): 517-38.

Quast, Dieter

2010 Ein spätantikes Zepter aus dem Childerichgrab. Archäologisches Korrespondenzblatt 40: 285-96.

Redknap, Martin

2006 Viking settlements in Wales: Some recent advances. Transactions of the Honourable Society of Cymmrodorion 12 (new series): 5-35.

Resi, Heid G

2011 Whetstones, grindstones, touchstones and smoothers. In Things from the town: Artefacts and inhabitants in Viking-age Kaupang, Norske Oldfunn, vol 24, edited by D. Skre, pp. 373-93. Aarhus Universitetsforlag, Aarhus.

Schjødt, Jens Peter

2008 Initiation between Two Worlds: Structure and Symbolism in Pre-Christian Scandinavian Religion. The Viking Collection 17. University of Southern Denmark, Odense.

Schulze, Hella

1987 Köpings socken. In Ölands järnåldersgravfält 1, edited by M. Beskow Sjöberg, pp. 21-138.

Riksantikvarieämbetet och Statens historiska museer, Stockholm.

Simpson, Jacqueline

1979 The King's Whetstone. Antiquity 53 (208): 96-101.

Söderberg, Bengt

2003 Järnålderns Järrestad: Bebyggelse, kronologi, tolkningsperspektiv. In Järrestad: Huvudgård $i$ centralbygd, edited by B. Söderberg, pp. 109-74. Riksantikvarieämbetets förlag, Stockholm

2005 Aristokratisk rum och gränsöverskridande: Järrestad och sydöstra Skåne mellan region och rike 600-1100. Riksantikvarieämbetets förlag, Stockholm

Sørensen, Palle $\varnothing$

Forthcoming Gudme, vol. I, Buildings and Environment. Publications from the National Museum, Odense University Press, Odense.

Stöllner, Thomas

2007 Handwerk im Grab - Handwerker? Überlegungen zur Aussagenkraft der Gerätebeigabe in eisenzeitlichen Gräbern. In Interpretierte Eisenzeit. Fallstudien, Methoden, Theorie.

Tagungsbeiträge der 2. Linzer Gespräche zur interpretativen Eisenzeitarchäologie, edited by K.

Raimund and J. Leskovar, pp. 227-52. Land Oberösterreich, OÖ. Landesmuseum, Linz.

Sundqvist, Olof

2007 Kultledare i fornskandinavisk religion. Occasional Papers in Archaeology 41. Department of Archaeology and Ancient History, Uppsala University, Uppsala.

Storm, Gustav and Alexander Bugge

1914 Norges Kongesagaer. I. M. Stenersens Forlag, Kristiania

Thomsen, Lone $\mathrm{G}$

Forthcoming The pit houses at Tissø. In Pre-Christian Cult Sites, Tissø vol.1: Landscape, buildings and organisation, edited by J. F. Bican, M. D. Jessen and L. Jørgensen, Publications from the National Museum, Denmark.

Whitridge, Peter

2016 Fractal Worlds - An Archaeology of Nested Spatial Scales. Arctic, vol. 69, suppl. 1: 1-10.

Wright, Duncan W.

2019 Crafters of Kingship: Smiths, Elite Power, and Gender in Early Medieval Europe. Medieval Archaeology 63 (2): 271-97. 